\title{
Application of Aquatic Plant Ceratophyllum demersum (L.) in Phytoremediation of Wastewater
}

\begin{abstract}
Background: Phytoremediation, plant usage for remediating natural resources, is being sought as a modern method to clean up polluted lands and streams, including water from ground. Bioremediation assisted by plant, also known as phytoremediation and includes the involvement of microbes associated with certain root systems to remediate soils comprising elevated organic compound concentrations. These strategies could provide cheaper methods for remediating polluted lands and streams with radionuclides, chemicals and different types of organics, with less secondary contaminants and less environmental effect than traditional methods of remediation can produce. All plants consume essential nutrients from their soil and water conditions like metals.

Methods: The domestic wastewater quality was determined by analyzing physico-chemical parameters like pH, TDS, TS and electrical conductivity, dissolved oxygen, biochemical oxygen demand, chemical oxygen demand, calcium, potassium, magnesium, sulphate, phosphate, nitrogen, iron and manganese and contaminant removal indices were determined during the year 2018-19.

Result: The present study was conducted to check the phytoremediation capability of aquatic plant Ceratophyllum demersum (L.). Wastewater was characterized using standard methods and pollutant concentrations were measured in sample of wastewater initially and after phytoremediation. The result of present study revealed maximum increase in value of DO $(127.89 \%)$ while the other parameters viz. pH (7.24\%), TDS (46.77\%), TS (51.00\%), BOD (60.79\%), COD (58.88\%), EC (49.89\%), Ca (45.41\%), K (46.58\%), Mg (43.57\%), S $(45.21 \%), \mathrm{P}(43.73 \%), \mathrm{N}(42.80 \%), \mathrm{Fe}(46.30 \%)$ and $\mathrm{Mn}(47.06 \%)$ recorded a decrease in 60 days at $40 \%$ value due to absorption of nutrients during phytoremediation.
\end{abstract}

Key words: Ceratophyllum demersum (L.), Phytoremediation, Wastewater.

\section{INTRODUCTION}

Phytoremediation, plant usage for remediating natural resources, is being sought as a modern method to clean up polluted lands and streams, including water from ground. All plants consume essential nutrients from their soil and water conditions like metals. Some plants, known as hyperaccumulators, have the capacity to hold vast quantities of metals, including those metals that may not seem to be appropriate for plant activity. Aquatic plants have played a part in the management of wastewater since early 1960 (Wooten and Dodd, 1976). Plants are grouped into emerging, floating leaves, submerged and free (not substratum) depending on their leaf relationship and growth form with water (Sood et al. 2012).

Ceratophyllum demersum (L.), widely known as rigid hornwort, BSBI List (2007) coon tail or coontail is a genus of Ceratophyllum. This is a submerged marine with a cosmopolitan range, stems of an aquatic plant, Ceratophyllum demersum (L.), exceed 1 to $3 \mathrm{~m}$ lengths, with several side shoots that render one specimen show as a wide, bushy mass. Leaves with 6 to 12 whorls are $8 \mathrm{~mm}$ to $40 \mathrm{~mm}$ long, forked or simple, into 2 to 8 thread-like segments; they are brittle and stiff. The fruit is a 4 to $5 \mathrm{~mm}$ long small seed, typically with 3 spines, 2 basal spines and 1 apical spine, 1 to 12 Ceratophyllum demersum (L.) grows with summer temperatures of water between 15 to $30^{\circ} \mathrm{C}$ and a rich nutrient condition in reservoirs, ponds and still streams. Ceratophyllum demersum (L.) develops in water which is still or very slow-moving. It is usually favored by
Department of Botany, Bundelkhand University, Jhansi-284 128, Uttar Pradesh, India.

${ }^{1}$ Department of Botany, D.A.V. College, Kanpur-208 001, Uttar Pradesh, India.

Corresponding Author: Amit Pandey, Department of Botany, Bundelkhand University, Jhansi-284 128, Uttar Pradesh, India. Email: pandeyamit0076@gmail.com

How to cite this article: Mohan, J., Pandey, A. and Singh, V. (2022). Application of Aquatic Plant Ceratophyllum demersum (L.) in Phytoremediation of Wastewater. Agricultural Science Digest. DOI: $10.18805 /$ ag.D-5443.

Submitted: 07-07-2021 Accepted: 04-01-2022 Online: 17-01-2022

conditions rich in nitrate where it grows more abundantly (Goulder and Boatman, 1971).

C. demersum is a cosmopolitan underwater marine species that has probably destroyed a significant portion of its fascinating ability as of now. This has the benefits of becoming a constant lasting great winter in deeper water and being both by the asexual reproduction of damaged or completed stems and by the sexual reproduction of other plants. It has strong biological resistance and is growing reasonably quick. The water body alarming effect contributes to improvements in growth by changes in distribution of nutrients, but in addition to faster dispersal across water sources making for more impressive competition of less daunting organisms (Mohan et al. 2017). 


\section{MATERIALS AND METHODS}

\section{Study area}

Kanpur urban city was visited repeatedly during 2016-19 to exact information related to wastewater sites and aquatic plants. After survey for collection of pond water, wastewater and aquatic plants of the urban sites of Kanpur was collected during the months of January to March, 2018 for experimental purpose.

\section{Wastewater sampling and preparation}

The selection criteria for each site were based upon anthropogenic activities, presence or absence of aquatic plants and accessibility at the site. Water sampling from ponds was done in January and was taken from 15 to 30 $\mathrm{cm}$ below the water surface. The waste water were collected from a point where drainage nala of polluted water mixing with Gangas water near Ganga Barrage, Azad Nagar, Kanpur. Samples were collected in wide mouth large plastic container and cork immediately and all the samples were brought all same day to settle in an open plastic tub in the research lab for one week to allow microorganisms to break down the solid organic water. The waste water then filtered and stored at $4^{\circ} \mathrm{C}$ temperature in a refrigerator till before treatment analysis was completed. Care was taken to prevent under shaking of the sample and also against the sun light while transporting them to the laboratory.

\section{Aquatic plant sample}

Ceratophyllum demersum (L.) plants which serve as tool of phytoremediation were collected from natural sites. In research laboratory of Botany department, they were rinsed with tap water to remove possible contamination were cultured into three different plastic tubs. After a week plants were transferred to three different small plastic containers filled with pond water. Approximately $4 \mathrm{gm}$ of Ceratophyllum demersum (L.) were inoculated in each disc. Three replicate were taken for each treatment. Experiment was carried out from February 2018. The treatment level for experiment were:- (i) Control (pond water), (ii) 20 per cent waste water, (iii) 40 per cent waste water, (iv) 60 per cent waste water, (v) 80 per cent waste water , (vi) 100 per cent waste water.

For analysis, samples were drawn and estimations were made for physico-chemical characteristics of waste water before and after treatment of 15,30 and 60 days growth of Ceratophyllum demersum (L.) plants.

\section{Sample analysis}

Ecological efficiency of Ceratophyllum demersum (L.) in phytoremediation of nutrients from domestic wastewater was studied in vitro. The domestic wastewater quality was determined by analyzing physico-chemical parameters. Instrumental analysis was done for physical parameters like $\mathrm{pH}$, TDS, TS and electrical conductivity (Tripathi and Govil, 2001). Chemical parameters viz. dissolved oxygen (Winkler,1888), biochemical oxygen demand (Greenberg et al., 1980) chemical oxygen demand (Tripathi and Govil, 2001) were analyzed titrimetrically while, calcium (Wallace,
1951), potassium (Wallace, 1951), magnesium (Mason, 1950), sulphate (Chesnin and Yen, 1951), phosphate (Wallace, 1951), Nitrogen (Kjeldahl, 1883), iron (Humphries, 1956) and manganese (Nicholas and Fischer, 1950) contents were determined by spectrophotometric method. contaminant removal indices (Liu et al. 2016) were determined by using prescribed formula.

\section{RESULTS AND DISCUSSION pH}

After treatment with aquatic plant Ceratophyllum demersum (L.) the $\mathrm{pH}$ value reduced maximum in 15,30 and 60 days is at $40 \%$ of wastewater i.e. $4.07 \%, 6.10 \%$ and $7.24 \%$. The results indicated that $\mathrm{pH}$ value was significantly decreased when treated with Ceratophyllum demersum (L.) (Beheary et al. 2019) (Table 1).

\section{Total dissolve solids (TDS)}

After treatment with aquatic plant Ceratophyllum demersum (L.) the TDS value reduced maximum in 15,30 and 60 days is at $40 \%$ of wastewater i.e. $19.16 \%, 33.13 \%$ and $46.77 \%$. TDS value was observed between 261.40 and 563.80 ppm after phytoremediation with Ceratophyllum (Patel and Kanungo, 2010). Saha et al. (2015) reported that the phytoremediation technique has the capacity to reduce TDS levels in wastewater. When comparing the reduction percent of TDS among treatments and control, we found that treatment with Ceratophyllum demersum (L.) reduced TDS by $33.8 \%$ (Beheary et al. 2019) (Table 1).

\section{Total solids (TS)}

After treatment with aquatic plant Ceratophyllum demersum (L.) the TS value reduced maximum in 15, 30 and 60 days is at $40 \%$ of wastewater i.e. $25.13 \%, 41.05 \%$ and $51.00 \%$. Our findings are in support with Beheary et al. (2019) that showed reduction in TS from 483.25 to 319.75 (Table 1).

\section{Biochemical oxygen demand (BOD)}

After treatment with aquatic plant Ceratophyllum demersum (L.) the BOD value reduced maximum in 15,30 and 60 days is at $40 \%$ of wastewater i.e. $35.22 \%, 49.19 \%$ and $60.79 \%$. The BOD was 10 to $20 \mathrm{mg} / \mathrm{l}$ after treatment with Ceratophyllum demersum (L). The drop was between 94.6 and $97.5 \mathrm{mg} / \mathrm{l}$. The oxidation phase reduced by 78.3 to 83.8 (Kulasekaran et al. 2014). The findings were in accordance with the White and Cousins (2013) indications that floating wetlands would benefit from improved particle sedimentation and promoting the removal of nutrients and metals.

\section{Chemical oxygen demand (COD)}

After treatment with aquatic plant Ceratophyllum demersum (L.) the COD value reduced maximum in 15, 30 and 60 days is at $40 \%$ of wastewater i.e. $40.36 \%, 51.55 \%$ and $58.88 \%$. The calculated COD was decreased from $664 \mathrm{mg} / \mathrm{L}$ to 152.75 $\mathrm{mg} / \mathrm{l}$ and from $260.5 \mathrm{mg} / \mathrm{L}$ to $64.5 \mathrm{mg} / \mathrm{l}$ in each year (Foroughi et al. 2010). In the design calculations for anticipated disposal of toxins by aquatic floating plants (Zimels et al. 


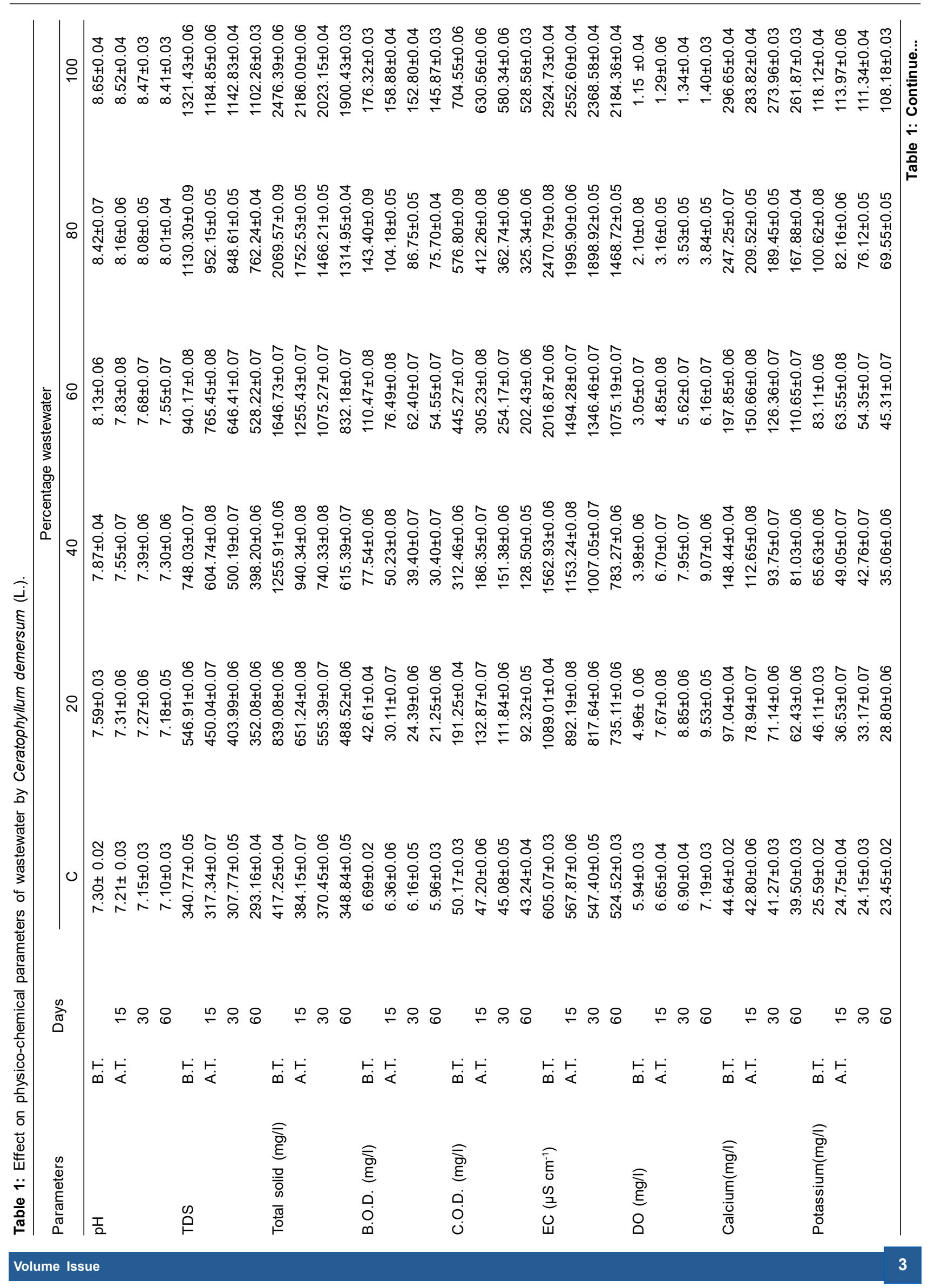


|

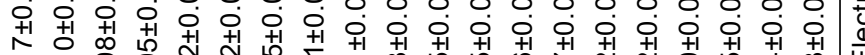

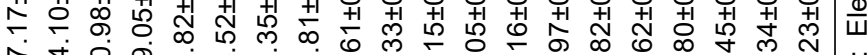

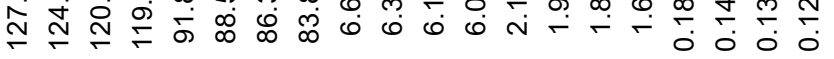

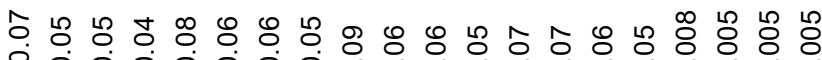

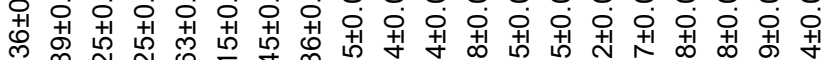

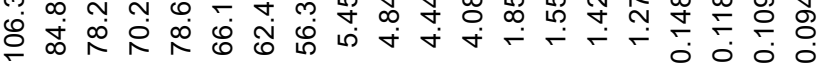

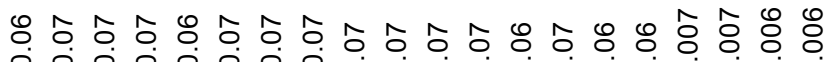

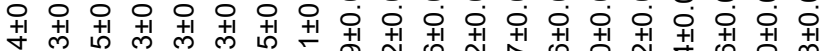

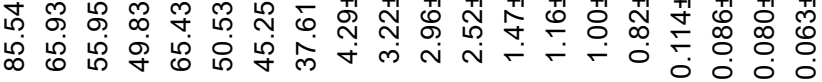

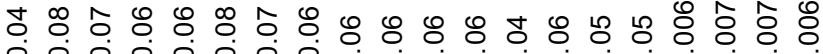

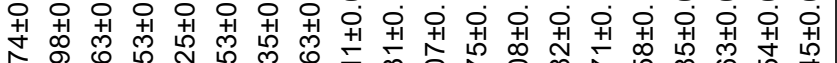

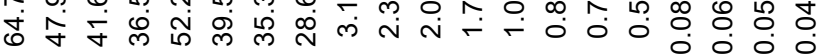

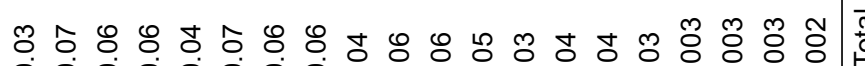

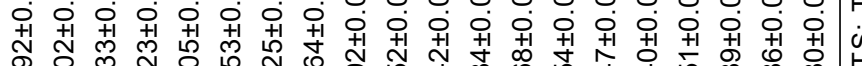
宁

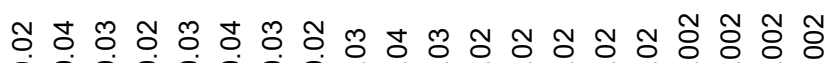

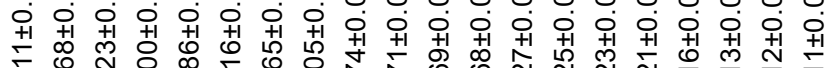

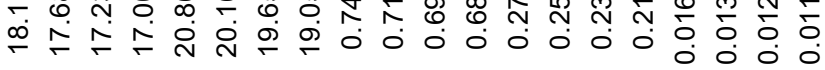

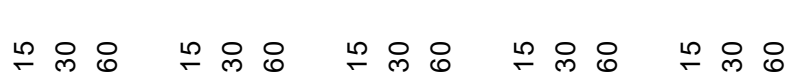

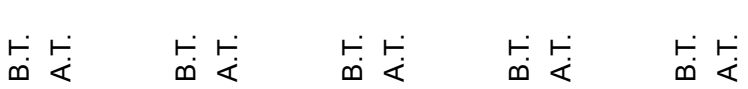


2009) have demonstrated that they can minimise the COD and increase dissolved oxygen. In another study, Ceratophyllum demersum (L.) treated wastewater contained between 30 and $55 \mathrm{mg} / /$ and the percentage drop was between 93.3 and 96.8 (Kulasekaran et al. 2014).

\section{Electrical conductivity (EC)}

After treatment with aquatic plant Ceratophyllum demersum (L.) the EC value reduced maximum in 15, 30 and 60 days is at $40 \%$ of wastewater i.e. $26.21 \%, 35.57 \%$ and $49.89 \%$. Due to the absorption by Ceratophyllum demersum (L.) of dissolved solids during the phytoremediation, the EC value was lowers following culture (Patel and Kanungo, 2010). Our results are also in agreement with that of Foroughi et al. (2014), who found that the EC values in diluted fresh latex wastewater was reduced by the use of $\mathrm{Cd}$ from 0.75 to $0.65 \mathrm{ds} / \mathrm{l}$.

\section{Dissolve oxygen (DO)}

After treatment with aquatic plant Ceratophyllum demersum (L.) the DO value increased maximum in 15, 30 and 60 days is at $40 \%$ of wastewater i.e. $68.34 \%, 99.75 \%$ and $127.89 \%$. After the phytoremediation with Ceratophyllum demersum (L.), DO value had an opposite pattern to other parameters, varies $5.3-8.3 \mathrm{mg} / \mathrm{L}$. The dissolved oxygen content was improved after phytoremediation (Patel and Kanungo, 2010).

\section{Calcium (Ca)}

After treatment with aquatic plant Ceratophyllum demersum (L.) the $\mathrm{Ca}$ value reduced maximum in 15, 30 and 60 days is at $40 \%$ of wastewater i.e. $24.11 \%, 36.84 \%$ and $45.41 \%$. Also in the seven-days culture of aquatic plants Das, 2005 reported reductions in sewage calcium. Percentage reduction in value after the phytoremediation varies from 14.74 to 26.74 for calcium (Patel and Kanungo, 2010).

\section{Potassium}

After treatment with aquatic plant Ceratophyllum demersum (L.) the potassium value reduced maximum in 15,30 and 60 days is at $40 \%$ of wastewater i.e. $25.26 \%, 34.85 \%$ and $46.58 \%$. Analysis of $\mathrm{K}$ after 18 days indicates a statistically significant decrease in $\mathrm{K}$ (Foroughi et al. 2014).

\section{Magnesium (Mg)}

After treatment with aquatic plant Ceratophyllum demersum (L.) the $\mathrm{Mg}$ value reduced maximum in 15, 30 and 60 days is at $40 \%$ of wastewater i.e. $25.89 \%, 35.70 \%$ and $43.57 \%$. The magnesium content in sewage was also reduced after the seven days cultivation of aquatic plants (Das, 2005). Another research showed that after phytoremediation, the percentage decrease in value of magnesium was 11.7753.65 per cent (Patel and Kanungo, 2010).

\section{Sulphur (S)}

After treatment with aquatic plant Ceratophyllum demersum (L.) the sulphur value reduced maximum in 15, 30 and 60 days is at $40 \%$ of wastewater i.e. $24.35 \%, 32.35 \%$ and $45.21 \%$.

\section{Phosphorus (P)}

After treatment with aquatic plant Ceratophyllum demersum (L.) the $P$ value reduced maximum in 15, 30 and 60 days is at $40 \%$ of wastewater i.e. $25.72 \%, 33.44 \%$ and $43.73 \%$. Reddy et al. 1990 studied the deposition by aquatic plants of different nutrients according to the relative aquatic population. Similar results were also obtained by Patel and Kanungo (2010). In minimising $P$ levels of enriched nutrient waters, submerged macrophytes may be used (Gao et al. 2009). C. demersum (L.) formation in shallow lakes with a heavy phosphorous load has been demonstrated (Mjelde and Faafeng, 1997).

\section{Nitrogen (N)}

After treatment with aquatic plant Ceratophyllum demersum (L.) the $\mathrm{N}$ value reduced maximum in 15,30 and 60 days is at $40 \%$ of wastewater i.e. $24.10 \%, 33.83 \%$ and $42.80 \%$. Ceratophyllum demersum (L.) treatment was the best in removing ammonia content with $3.44 \%$ (Beheary et al. 2019).

\section{Iron (Fe)}

After treatment with aquatic plant Ceratophyllum demersum (L.) the Fe value reduced maximum in 15, 30 and 60 days is at $40 \%$ of wastewater i.e. $24.07 \%, 34.26 \%$ and $46.30 \%$. Based on results the most adsorption happened after six days (Foroughi et al. 2011). The nutrients taken from the water include unradicated submerged vegetation, including Ceratophyllum demersum (L.) (Mjelde and Faafeng, 1997).

\section{Manganese (Mn)}

After treatment with aquatic plant Ceratophyllum demersum (L.) the Mn value reduced maximum in 15, 30 and 60 days is at $40 \%$ of wastewater i.e. $25.88 \%, 36.47 \%$ and $47.06 \%$. The quantity of Mn taken from C. demersum was $94.21 \%$ of RMW and $90.82 \%$ of TMW (Foroughi et al., 2011). It is long established that all live and dead aquatic plants are heavy metal accumulators, which has led to a high degree of involvement from use of aquatic plants to extract heavy metals from wastewater (Lacher and Smith, 2002).

\section{CONCLUSION}

Phytoremediation is still in a phase of development and research and requires immense efforts to overcome technical barriers. Ceratophyllum demersum (L.) was found to be efficient in reducing the concentration of $\mathrm{pH}$, TDS, TS, BOD, COD, EC, Ca, K, Mg, S, P, N, Fe and Mn within 60 days of treatment. This study concludes that Ceratophyllum demersum (L.) has proved to be promising tool for wastewater treatment more attention is required to make it publically applicable and accepted.

\section{REFERENCES}

Americal Public Health Association. (1995). Standard Methods for the Examination of Water and Waste Water, 19 ${ }^{\text {th }} \mathrm{Ed}$. New York. 
Beheary, M., Sheta, B.M., Hussein, M., Nawareg, M., El-Matary F.A., Hyder, A. (2019). Environmental remediation of tilapia aquaculture wastewater using Ceratophyllum demersum and lemna minor. Egyptian Journal of Aquatic Biology and Fisheries. 23(2): 379- 396.

BSBI List. (2007). Botanical Society of Britain and Ireland. Archived from the original (xls) on 2015-01-25.

Chesnin, L., Yen, C.R. (1951). Turbidimetric determination of available sulphates. Soil Science Soc. Amer. Proc. 15: 149-151.

Das, A.K. (2005). Studies on biremediation of municipal sewage with reference to macrophytes. Ind. J. Environ. and Ecoplan. 10(3): 965-971.

Foroughi, M., Najafi, P., Toghiani, A., Honarjoo, N. (2010). Analysis of pollution removal from wastewater by Ceratophyllum demersum. African Journal of Biotechnology. 9(14): 2125-2128.

Foroughi, M., Najafi, P., Toghiani, S. (2011). Trace elements removal from waster water by Ceratophyllum demersum. J. Appl. Sci. Environ. Manage. 15(1): 197-201.

Foroughi, M., Najafi, P., Toghiani, S., Honarjoo, N. (2014). Using Ceratophyllum demersum for treatment of saline municipal wastewater. J. Residuals Sci. Technol. 11(2): 45-48.

Gao, J., Xiong, Z.H., Zhang, J., Zhang, W., Obono, M.F. (2009). Phosphorous removal from water of eutrophic Lake Donghu by five submerged macrophytes. De salination. 242: $193-204$

Goulder R., Boatman, D.J. (1971). Evidence that the nitrogen supply influences the distribution of a freshwater macrophyte, Ceratophyllum demersum. Journal of Ecology. 59: 783-791.

Greenberg, A.A., Connors, J.J., David, J. (1980). Standard Methods for the Examination of Water and Waste Water. $15^{\text {th }} \mathrm{Ed}$. APHA, Washington, USA.

Humphries, E.C. (1956). Mineral components and ash analysis in "Modern Methoden der Pflanzenanelyse" B and I.Ed. K. Peach U.M.V. Treacey. Verleg. Berlin, Zeite. 468-502.

Kjeldahl, J. (1883). A new method for the determination of nitrogen in organic matter. Z. Anal. Chem. 22: 366.

Kulasekaran, A., Gopal, A., John A.J. (2014). A study on the removal efficiency of organic load and some nutrients from sewage by Ceratophyllum demersum (L.). J. Mater. Environ. Sci. 5(3): 859-864.

Lacher, C., Smith, R.W. (2002). Sorption of Hg by Potamogeton natans dead biomass. Min Eng. 15: 187-191.

Liu, J.T., Sun, J.J., Fang, S.W., Han, L., Feng, Q., Hu, F. (2016). Nutrient removal capacities of four submerged macrophytes in the Poyang lake basin. Appl Ecol Environ Res. 14(2): 107-124.
Mason, A.C. (1950). The estimations of phosphorus, potassium, calcium, magnesium, iron, manganese and nitrogen in plant material. Ann. Rept., East Malling, Res. Sta. 111-115.

Mjelde, M., Faafeng, B.A. (1997). Ceratophyllum demersum Hampers phytoplankton development in some small Norwe Gian lakes over awide range of phosphorus concentrations and Geographic allatitude. Fresh Water Biol. 37: 355-365.

Mohan, J., Shakya, N.B., Shukla, N. K., Kumar, V. (2017). Studies on phytoremediation of municipal waste water with reference to aquatic plant Ceratophyllum demersum. Annals of Plant Sciences. 6 (12): 1918-1921.

Nicholas, D.J.D., Fischer, D.J. (1950). A note on the use of tetramethylmethane for determining small amount of manganese in plants. Annu. Rep. Long Ashton. Res. Sta. Bristol. 1(20): 115-120.

Patel D.K., Kanungo, V.K. (2010). Phytoremediation potential of duckweed (Lemna minor L: A Tiny Aquatic Plant) in the removal of pollutants from domestic wastewater with special reference to nutrients. The Bioscan. 5(3): 355358.

Reddy, K.R., Agami, M., Tuckker, J.C. (1990). Influence of phosphorus on growth and nutrient storage by water hyacinth [Eichhornia crassipes (Mart) Solms] plant. Aquatic Botany. 13: 355-365.

Saha, P., Banerjee, A., Sarkar S. (2015). Phytoremediation potential of duckweed (Lemna minor L.) on steel wastewater. Int. J. Phytoremediation. 17: 589-596.

Sood, A., Uniyal, P.L., Prasanna, R., Ahluwalia, A.S. (2012). Phytoremediation potential of aquatic macrophyte, Azolla. AMBIO. 41(2): 122-137.

Tripathi, B.D., Govil, S.R. (2001). Water Pollution (An Experimental Approach). CBS Publishers and Distributers, New Delhi.

Wallace, T. (1951). The Diagnosis of mineral deficiencies in plant. A colour allas and guide H.M.S.C., London.

White, S.A., Cousins, M.M. (2013). Floating treatment wetland aided remediation of nitrogen and phosphorus from simulated stormwater runoff. Ecol. Eng. 61: 207-215.

Winkler, L.W. (1888). The determination of dissolve oxygen in water. Berlin. Deut. Chem. Ges. 21: 2843.

Wooten, J.W., Dodd, J.D. (1976). Growth of water hyacinths in treated sewage effluent. Econ. Bot. 30(1): 29-37.

Zimels, Y., Kirzhner, F., Kadmon, A. (2009). Effect of circulation and aeration on wastewater treatment by floating aquatic plants. Separation and Purification Technology. 66(3 and 7): $570-577$. 